\title{
Incompatibility properties of the narrow-host-range lactococcal plasmid pCI305
}

\author{
Sophie Foley, ${ }^{1}$ Charles Daly ${ }^{1,2}$ and Gerald F. FitzGerald ${ }^{1 *}$ \\ ${ }^{1}$ Department of Food Microbiology, and ${ }^{2}$ National Food Biotechnology Centre, University College, Cork, Ireland
}

(Received 22 October 1992; revised 18 January 1993; accepted 29 January 1993)

\begin{abstract}
The cryptic plasmid pCI305 from Lactococcus lactis subsp. lactis UC317 was screened for incompatibility with a range of cloning vectors and was found to be incompatible with the theta-replicating plasmids pAM401 and pIL253. In contrast, lactococcal vectors containing the replication functions of the rolling circle replicating plasmids pSH71 and pWV01 were compatible with pCI305. A number of native lactococcal plasmids were also screened for both incompatibility and DNA sequence homology to the pCI305 replicon. A plasmid with high sequence identity was identified which was compatible with $\mathrm{pCI} 305$.
\end{abstract}

\section{Introduction}

Lactococcus lactis strains are widely used in the manufacture of a range of fermented food products and consequently are of considerable industrial and economic importance. Many of the key technological traits of these bacteria, e.g. proteinase activity (Prt), lactose metabolism (Lac) and bacteriophage resistance mechanisms such as abortive infection (Abi) and adsorption inhibition (Ads), are plasmid-encoded and have been studied extensively (de Vos, 1986). However, there is little information available concerning the intrinsic properties of these plasmids, e.g. replication mechanisms, stability and incompatibility functions. Knowledge of these characteristics is essential for the construction of strains of lactococci with improved technical traits and enhanced reliability.

The replication characteristics of a number of small lactococcal plasmids, used to construct a range of cloning vectors for the genetic manipulation of lactic acid bacteria, have been described. These molecules, which include pSH71 (de Vos, 1986, 1987) and pWV01 (Leenhouts et al., 1991), replicate by a rolling circle replication (RCR) mechanism (Gruss \& Ehrlich, 1989) which may explain their high structural and segregational instability (Bron \& Luxen, 1985; Bron et al., 1988; Ehrlich et al., 1986). Hayes et al. (1990) identified a small cryptic plasmid, pCI305, from $L$. lactis subsp. lactis UC317 which, unlike the replicons described above, is

\footnotetext{
* Author for correspondence. Tel. 35321276871 ext. 2730; fax 353 21275934.
}

extremely stable (both structurally and segregationally) and has a narrow host-range. The inability to detect single-stranded DNA (an intermediate of RCR) and the lack of DNA sequence homology to the highly conserved replication regions of RC plasmids (Hayes et al., 1991) would suggest that pCI305 probably uses a theta-mode of replication. In addition, several features of the pCI305 minimal replicon are to be found in many of the thetareplicating plasmids from Gram-negative bacteria, e.g. pSC101 (Manen \& Caro, 1991), RSF1010 (Persson \& Nordstrom, 1986) and R1162 (Lin et al., 1987).

An important intrinsic characteristic of plasmids which needs to be considered when devising strain improvement strategies relates to incompatibility. Bacterial plasmids that share either replication control or partitioning functions and which compete for stable inheritance are termed incompatible and are placed in the same incompatibility group (Novick et al., 1976). A study of incompatibility groups amongst native lactococcal plasmids should provide considerable information concerning the evolutionary relatedness of these molecules and could lead to the construction of different classes of stable cloning vectors which can avoid incompatibility reactions when used in various lactococcal hosts. Thus far there have been no comprehensive reports concerning plasmid incompatibility in lactic acid bacteria. However, incompatibility has been shown to result in plasmid curing in L. lactis subsp. cremoris $\mathrm{Wg} 2$ (van der Lelie et al., 1988), Lactobacillus pentosus (Posno et al., 1991), Lb. acidophilus (Muriana \& Klaenhammer, 1987) and Lb. plantarum (Bringel et al., 1989).

In this paper the incompatibility properties of the 
Table 1. Bacterial strains and plasmids

\begin{tabular}{|c|c|c|}
\hline Strain or plasmid & Characteristics & Reference or source \\
\hline \multicolumn{3}{|l|}{ L. lactis subsp. lactis } \\
\hline MG1363 & $\begin{array}{l}\mathrm{Lac}^{-} \mathrm{Prt}^{-} \mathrm{Sm}^{\mathrm{r}} \text { plasmid-free derivative of } L \text {. lactis } \\
\text { NCDO } 712\end{array}$ & Gasson (1983) \\
\hline MG1614 & $\mathrm{Lac}^{-} \mathrm{Prt}^{-} \mathrm{Sm}^{\mathrm{r}} \mathrm{Rif}^{\mathrm{r}}$ derivative of $\mathrm{MG} 1363$ & Gasson (1983) \\
\hline FH052 & MG1363Sm $\mathrm{Sm}^{\mathrm{r}}$ harbouring pCI305 & Hayes et al. (1990) \\
\hline FH 136 & MG1363Sm ${ }^{\mathrm{r}}$ harbouring pCI350 & Hayes et al. (1990) \\
\hline MG1299 & MG1363Sm ${ }^{\mathrm{r}}$ harbouring $\mathrm{pLP} 712$ & Gasson (1983) \\
\hline UC505 & MG1363Sm ${ }^{\mathrm{r}}$ harbouring pCI528 & Costello (1988) \\
\hline $\mathrm{AC} 002$ & MG1363Sm ${ }^{\mathrm{r}}$ harbouring pCI829 & Coffey et al. (1989) \\
\hline $\mathrm{AC} 004$ & MG1363Sm ${ }^{r}$ harbouring pCI842 & Coffey et al. (1989) \\
\hline MM106 & LM2306 harbouring pCi726 & Murphy (1988) \\
\hline $\mathrm{AB} 002$ & MG1614 harbouring pC1750 & Baumgartner et al. (1986) \\
\hline $\mathrm{DPC} 3260$ & MG1614 harbouring pNP40 & Harrington \& Hill (1991) \\
\hline \multicolumn{3}{|l|}{ Plasmids } \\
\hline $\mathrm{pC} 1305$ & $\begin{array}{l}8.7 \mathrm{~kb} \text { cryptic plasmid from } L . \text { lactis } \\
\text { subsp. lactis UC } 317\end{array}$ & Hayes et al. (1990) \\
\hline $\mathrm{pC} 1350$ & $\begin{array}{l}\text { pCI305 cloned into replication probe } \\
\text { vector pCI } 341, \mathrm{Cm}^{\mathrm{r}}(11 \cdot 8 \mathrm{~kb})\end{array}$ & Hayes et al. (1990) \\
\hline $\mathrm{pC} 1369$ & $\begin{array}{l}2.6 \mathrm{~kb} \text { replicon of pCI305 subcloned into } \\
\text { pCI341, } \mathrm{Cm}^{\mathrm{r}}(5.7 \mathrm{~kb})\end{array}$ & Hayes et al. (1990) \\
\hline pCI374 & $\begin{array}{l}1.8 \mathrm{~kb} \text { replicon of pCI305 subcloned into } \\
\text { pCI341, } \mathrm{Cm}^{\mathrm{r}}(4.9 \mathrm{~kb})\end{array}$ & Hayes et al. (1990) \\
\hline pAM401 & $\mathrm{Cm}^{\mathrm{r}} \mathrm{Tc}^{\mathrm{r}}$, pIP501 replicon $(10.4 \mathrm{~kb})$ & Wirth et al. (1986) \\
\hline pIL253 & $\mathrm{Em}^{\mathrm{r}}, \mathrm{pAM} \beta 1$ replicon $(4.8 \mathrm{~kb})$ & Simon \& Chopin (1988) \\
\hline pGKV210 & $\mathrm{Em}^{\mathrm{r}}, \mathrm{pWV} 01$ replicon $(4.4 \mathrm{~kb})$ & van der Vossen et al. (1985) \\
\hline pGKV110 & $\mathrm{Em}^{\mathrm{r}}$, pWV01 replicon $(4 \cdot 4 \mathrm{~kb})$ & van der Vossen et al. (1985) \\
\hline pNZ521 & $\mathrm{Cm}^{\mathrm{r}} \mathrm{Km}^{\mathrm{r}}, \mathrm{pSH} 71$ replicon $(10.5 \mathrm{~kb})$ & de Vos et al. (1989) \\
\hline pCI3601 & $\mathrm{Cm}^{\mathrm{r}} \mathrm{Km}^{\mathrm{r}}, \mathrm{pSH} 71$ replicon $(10.5 \mathrm{~kb})$ & Law et al. (1992) \\
\hline pNP40 & $\begin{array}{l}\text { Abi Nis }{ }^{\mathrm{r}} \text { plasmid }(64 \mathrm{~kb}) \text { of } L \text {. lactis } \\
\text { subsp. lactis biovar. diacetylactis } \mathrm{DRC} 3\end{array}$ & McKay \& Baldwin (1984) \\
\hline pCI528 & $\begin{array}{l}\text { Ads plasmid }(46 \mathrm{~kb}) \text { of } L . \text { lactis subsp. } \\
\text { cremoris } \mathrm{UC} 503\end{array}$ & Costello (1988) \\
\hline pCI829 & $\begin{array}{l}\text { Abi plasmid }(44 \mathrm{~kb}) \text { of L. lactis subsp. } \\
\text { lactis UC811 }\end{array}$ & Coffey et al. (1989) \\
\hline pCI842 & $\begin{array}{l}\mathrm{Lac}^{+} \text {plasmid }(61 \mathrm{~kb}) \text { of L. lactis subsp. } \\
\text { lactis UC811 }\end{array}$ & Coffey et al. (1989) \\
\hline $\mathrm{pCI} 750$ & $\begin{array}{l}\text { Abi plasmid }(65 \mathrm{~kb}) \text { of } L . \text { lactis subsp. } \\
\text { cremoris UC } 653\end{array}$ & Baumgartner et al. (1986) \\
\hline pCI726 & $\begin{array}{l}\mathrm{Lac}^{+} \text {plasmid }(40 \mathrm{~kb}) \text { of } L . \text { lactis subsp. } \\
\text { cremoris UC653 }\end{array}$ & Baumgartner et al. (1986) \\
\hline pLP712 & $\begin{array}{l}\text { Lac }^{+} \text {Prt }^{+} \text {plasmid }(51 \mathrm{~kb}) \text { of L. lactis } \\
\text { subsp. lactis } 712\end{array}$ & Gasson (1983) \\
\hline
\end{tabular}

narrow-host-range cryptic lactococcal plasmid pCI305 are described. This includes a study of the interactions of pCI305 with several native lactococcal plasmids, known to encode a variety of industrially important traits, and also with several frequently used cloning vectors.

\section{Methods}

Bacterial strains, media and reagents. The bacterial strains used in this study are described in Table 1. All lactococcal strains were routinely subcultured at $30^{\circ} \mathrm{C}$ in M17 medium (Terzaghi \& Sandine, 1975 ) supplemented with $0.5 \%$ glucose (GM17). Solid media contained $1.5 \%(\mathrm{w} / \mathrm{v})$ agar (Oxoid no. 3). Erythromycin and chloramphenicol were used when required at a final concentration of $5 \mu \mathrm{g} \mathrm{ml}^{-1}$.

Isolation of plasmid DNA and transformation procedures. Large-scale and rapid isolation of plasmid DNA from lactococci was achieved using the method described by Anderson \& McKay (1983). Purification of plasmid DNA by caesium chloride/ethidium bromide density gradients was performed as described by Maniatis et al. (1982). Lactococcal strains were transformed by electroporation using the procedure of Holo \& Nes (1989).

Southern hybridization. DNA (either unrestricted or linearized) was electrophoresed on $0.7 \%$ horizontal or vertical agarose gels, transferred to Hybond $\mathrm{N}^{+}$nylon filters by the method of Southern (1975) and hybridized with a DNA probe labelled using the Enhanced Chemiluminescence (ECL) gene detection system (Amersham). All protocols were performed as suggested by the suppliers. The DNA fragment used as the probe was recovered from an agarose gel using the Geneclean kit (Bio101).

Incompatibility studies. L. lactis cultures each containing a specific resident plasmid were transformed by electroporation with the test plasmid DNA and plated on a medium selective for the incoming plasmid. Transformants were grown in GM17 broth in the absence of antibiotic selection for $4 \mathrm{~h}$ (approximately four generations) and screened for the retention of the resident plasmid by agarose gel 
electrophoresis. Those transformants which were found to contain both plasmids were subcultured for 100 generations without selective antibiotic pressure. During this time the cultures were maintained in the exponential phase of growth by extensive dilution at $10 \mathrm{~h}$ intervals. After 50 and 100 generations, appropriate dilutions were plated on nonselective medium and subsequently 100 colonies were replica-plated onto selective plates. Up to 10 single colonies of each phenotype (antibiotic resistant/sensitive) were screened for the presence of the original resident plasmid, the transforming plasmid or both by agarose gel electrophoresis. The percentage of the population in which loss of a specific plasmid occurred was then determined.

\section{Results and Discussion}

\section{Screening of vector plasmids for incompatibility with pCI305}

Several cloning vectors commonly used in the genetic manipulation of lactococci were screened for incompatibility with $\mathrm{pCI} 305$. In these experiments the cryptic plasmid, pCI305, was the resident replicon and selection was for the incoming plasmid only. The results are described in Table 2. In all cases where loss of antibiotic resistance occurred, this was due to the elimination of the corresponding plasmid based on agarose gel electrophoresis analysis of plasmid content. Two types of incompatibility were detected. Incompatibility was first observed when chloramphenicol-resistant derivatives of pCI305 were used as the incoming plasmid. Examination of the plasmid content of antibiotic-resistant transformants following only three to four generations of growth in broth in the absence of selective pressure revealed that both the incoming and resident plasmids

\section{Table 2. Incompatibility between $p C I 305$ and a range of vector plasmids}

\begin{tabular}{lrrrrr}
\hline \hline \multicolumn{5}{c}{$\begin{array}{c}\text { Percentage of population } \\
\text { after 100 generations with: }\end{array}$} \\
\cline { 2 - 4 } Incoming & pCI305 & Incoming & & \\
plasmid & Both & Incompatibility Hybridization \\
plasmid & only & only & plasmids & with pCI305* & to pCI305§ \\
\hline pCI350 & 57 & 43 & 0 & INC & + \\
pCI369 & 63 & 37 & 0 & INC & + \\
pCI374 & 62 & 38 & 0 & INC & + \\
pAM401 & 100 & 0 & 0 & INC & - \\
pIL253 & 100 & 0 & 0 & INC & - \\
pGKV210 & 0 & 0 & 100 & COM & - \\
pGKV110 & 0 & 0 & 100 & COM & - \\
pNZ521 & 11 & 0 & 89 & COM $^{*}$ & - \\
pCI3601 & 33 & 0 & 67 & COM $^{*}$ & - \\
\hline \hline
\end{tabular}

$\dagger$ The host strain in each case was L. lactis subsp. lactis FH052 (MG1363 containing pCI305).

$\ddagger$ INC, $100 \%$ loss of one plasmid; COM, $100 \%$ coexistence of both plasmids; $\operatorname{COM}^{*}$, coexistence of both plasmids in $>60 \%$ of the population after 100 generations.

$\S$ The probe used was a $1.8 \mathrm{~kb} X b a \mathrm{I}-P s t \mathrm{I}$ fragment of $\mathrm{pCI} 374$ containing the $\mathrm{pCI} 305$ minimal replicon. were present. However, when this heteroplasmid strain was subcultured for 100 generations under nonselective conditions homoplasmid segregants were isolated (see Table 2). This type of incompatibility between pCI305 and its chloramphenicol-resistant derivatives was to be expected since all of these molecules have identical replication functions. It is likely that in this case plasmid incompatibility occurred due to the random selection, for replication and partitioning events, of individual copies of either molecule within the plasmid pool. According to Novick (1987), in such cases homoplasmid segregants will appear at a constant rate during growth of the heteroplasmid strain. When the same experiment was repeated with the modification of growing the antibiotic-resistant transformants, initially for four generations, in the presence of antibiotic selective for the incoming plasmid, a distortion of the average copy pool was observed (data not shown). This distortion was reflected in the ratio of homoplasmid segregants containing one or the other plasmid following 100 generations of growth in the absence of selective pressure (e.g. $81 \%$ of the population contained pCI369 in contrast to $37 \%$ when hosts were grown continuously in the absence of selective pressure).

Vectorial incompatibility (i.e. where one plasmid is lost exclusively; Novick, 1987) between pCI305 and the theta-replicating plasmids pAM401 and pIL253 was the second type of interaction observed (Table 2). The plasmid content of these antibiotic-resistant transformants was examined following only four generations of growth under non-selective conditions and in both cases only the resident plasmid, pCI305, was present. Therefore the incompatibility between these two plasmids (pAM401 and pIL253) and pCI305 results in rapid loss of the incoming plasmid in the absence of selective pressure. It has frequently been reported that when the incoming and resident plasmids are incompatible, transformation of the host occurs at a reduced efficiency (Bird \& Pittard, 1982; van der Lelie et al., 1988; Warren \& Sherratt, 1978). However, in the experiments described in this study the nature of the resident or incoming plasmid did not appear to alter transformation frequencies.

Both pAM401 and pIL253 use a theta-mode of replication (Brantl et al., 1990; Bruand et al., 1991) and may therefore be incompatible with $\mathrm{pCI} 305$ due to competition for a common factor involved in replication or partitioning. pIP501 and pAM $\beta 1$ (the sources of the pAM401 and pIL253 replicons, respectively) belong to the same incompatibility group on the basis that they are incompatible with each other and they share extensive similarities in the DNA sequence and organization of their replication regions (Brantl et al., 1990). However, no homology could be detected in hybridization experi- 
Table 3. Screening of native lactococcal plasmids for incompatibility with the $p C I 305$ replicon

\begin{tabular}{cccc}
\hline \hline $\begin{array}{c}\text { Resident } \\
\text { plasmid } \dagger\end{array}$ & $\begin{array}{c}\text { Relevant } \\
\text { phenotype }\end{array}$ & $\begin{array}{c}\text { Incompatibility } \\
\text { with pCI350 }\end{array}$ & $\begin{array}{c}\text { Hybridization } \\
\text { to pCI305§ }\end{array}$ \\
\hline pNP40 & Abi Nis & INC & - \\
pCI528 & Ads & COM & + \\
pCI829 & Abi & COM & $+^{*}$ \\
pCI842 & Lac & INC & $+^{*}$ \\
pCI750 & Abi & COM & - \\
pCI726 & Lac & COM* & + \\
pLP712 & Lac Prt & COM & - \\
\hline \hline
\end{tabular}

$\dagger$ The incoming plasmid used was pCI350 (a derivative of pCI305 harbouring a chloramphenicol-resistance determinant). The host strain was L. lactis subsp. lactis MG1363 for pCI528, pCI829, pCI842, pLP712; L lactis subsp. lactis MG1614 for pNP40 and pCI750; L. lactis subsp. lactis LM2306 for pCI726.

$\$ \mathrm{INC}, 100 \%$ loss of the incoming plasmid, pCI350; COM, $100 \%$ coexistence of both plasmids; $\mathrm{COM}^{*}$, coexistence of both plasmids in $51 \%$ of the population after 100 generations.

$\S$ The probe used was a $1.8 \mathrm{~kb}$ XbaI-PstI fragment of $\mathrm{pCI} 374$ containing the $\mathrm{pCI} 305$ minimal replication region. $+{ }^{*}$ represents weak hybridization.

ments between these plasmids and the minimal replication region of pCI305 (Table 2). The reasons for the strong incompatibility between $\mathrm{pCI} 305$ and replicons derived from $\mathrm{pAM} \beta 1$ and pIP501 are unknown. Since there is no DNA sequence homology between their replication regions it is possible that a segment of pCI305 outside of the minimal replicon is involved. Such a sequence could possibly encode a stability/maintenance function or a factor inhibitory to pAM401 and pIL253 replication or maintenance, resulting in complete loss of these plasmids in the presence of pCI305. Another possibility is that there is competition for a host factor between the plasmids and since pCI305 is a lactococcal plasmid it may have a distinct advantage in contrast to the pAM $\beta 1$ replicon of Enterococcus faecalis and pIP501 from Streptococcus agalactiae.

Cloning vectors based on the cryptic RC plasmids pSH71 (de Vos, 1987) and pWV01 (Leenhouts et al., 1991) were found to be compatible with pCI305 (Table 2) and as previously reported (Hayes et al., 1991), no DNA sequence homology to the minimal replicon of pCI305 was detected. It will thus be possible to examine the effect of specific sequences from the pCI305 minimal replicon on pCI305 replication when these sequences are provided in trans.

\section{Incompatibility between native lactococcal plasmids and} the pCI305 replicon

Numerous plasmids of enteric bacteria and Staphylococcus are very well characterized (in comparison to those of lactic acid bacteria) and many have been classified into incompatibility groups (Couturier et al., 1988; Iordanescu et al., 1978; Novick, 1989; Udo \& Grubb, 1991). Since plasmid incompatibility can occur due to competition for a common factor involved in plasmid replication or partitioning, a correlation has frequently been made between DNA sequence homology and incompatibility (e.g. the IncI group of enteric plasmids; Falkow et al., 1974). If such observations could be made amongst the lactococcal plasmids it would greatly facilitate the classification of these replicons. Such grouping of plasmids would provide considerable information concerning the evolutionary relatedness of these molecules within $L$. lactis subsp. lactis and cremoris.

An experiment by Hayes et al. (1991) in which the plasmid complements of eight multi-plasmid Lactococcus strains were screened for DNA homology to the pCI305 minimal replication region illustrated the widespread distribution of the 'pCI305-type' replicon. In Table 3 results are presented describing an experiment in which several native lactococcal plasmids with known functions were screened for incompatibility with pCI305. In all cases pCI350, a derivative of pCI305 harbouring a chloramphenicol-resistance determinant, was used as the incoming plasmid. The native plasmids were also screened for DNA sequence homology to the pCI305 replicon in order to identify those plasmids which were incompatible due to shared replication functions. The probe used was a $1.8 \mathrm{~kb}$ XbaI-PstI pCI374 fragment containing the minimal replicon of pCI305. Sequence analysis of this fragment indicated the absence of any of the known IS elements or transposons which are ubiquitous in lactococcal DNA. The results indicated that there was not necessarily a correlation between DNA sequence homology in the replication regions and incompatibility. This can be seen with pCI528, which exhibited extensive homology to the minimal replicon of pCI305 yet these two plasmids were compatible. In addition, plasmids were identified which were incompatible with pCI305 but this was not due to common replication functions. For example, the phage-resistance plasmid, pNP40, was incompatible with pCI350 but did not hybridize to the pCI305 probe (Table 3).

Comparison of the DNA sequence of the pCI528 replicon (M. Lucey, unpublished results) with that of pCI305 revealed greater than $70 \%$ homology. It was also observed in in vivo experiments that the replication protein of pCI528 could not act in trans on the replication origin (repA) of pCI305 (unpublished data). Thus it is likely that the sequence differences within the replication origin and the gene encoding the replication protein enable these plasmids to coexist and be stably maintained. Analysis of differences such as those between pCI305 and pCI528 should assist in elucidating the 
factors that determine plasmid incompatibility/compatibility and replication control.

Further analysis of these various interactions is required to understand how pCI305 is incompatible with the theta-replicating plasmids pIL253 and pAM401 and compatible with plasmids of high sequence identity, e.g. pCI528. This may result in the identification of functions outside of the minimal replicon which are responsible for the stable maintenance of pCI305. In addition, the identification of the specific nucleotide base differences between pCI528 and pCI305 that enable independent replication of these plasmids should contribute to our understanding of the replication mechanisms of pCI305 and related plasmids.

This work was supported by the European Community BRIDGE (contract BIO-CT91-0263) programme.

\section{References}

ANDERSON, D. G. \& MCKAY, L. L. (1983). A simple and rapid method for isolating large plasmid DNA from lactic streptococci. Applied and Environmental Microbiology 46, 549-552.

Baumgartner, A., Murphy, M., Daly, C. \& Fitzgerald, G. F. (1986). Conjugative co-transfer of lactose and bacteriophage resistance plasmids from Streptococcus cremoris UC653. FEMS Microbiology Letters 35, 233-237.

BiRD, P. I. \& PitTARD, J. (1982). An unexpected incompatibility interaction between two plasmids belonging to the I compatibility complex. Plasmid 8, 211-214.

Brantl, S., Behnke, D. \& Alonso, J. C. (1990). Molecular analysis of the replication region of the conjugative Streptococcus agalactiae plasmid pIP501 in Bacillus subtilis. Comparison with plasmids pAMB1 and pSM19035. Nucleic Acids Research 18, 4783-4790.

Bringel, F., Frey, L. \& Hubert, J.-C. (1989). Characterisation, cloning, curing and distribution in lactic acid bacteria of pLP1, a plasmid from Lactobacillus plantarum CCM 1904 and its use in shuttle vector construction. Plasmid 22, 193-202.

Bron, S. \& LuXEN, E. (1985). Segregational instability of pUB110derived recombinant plasmids in Bacillus subtilis. Plasmid 14, 235-244.

Bron, S., Luxen, E. \& Swart, P. (1988). Instability of recombinant pUB110 plasmids in Bacillus subtilis: plasmid encoded stability functions and effects of DNA inserts. Plasmid 19, 231-241.

Bruand, C., Ehrlich, S. D. \& Janniere, L. (1991). Unidirectional theta replication of the structurally stable Enterococcus faecalis plasmid pAM $\beta 1$. EMBO Journal 10, 2171-2177.

Coffey, A. G., Fitzgerald, G. F. \& Daly, C. (1989). Identification and characterisation of a plasmid encoding abortive infection from Lactococcus lactis subsp. lactis UC811. Netherlands Milk and Dairy Journal 43, 229-244.

Costello, V. (1988). Characterisation of bacteriophage-host interactions in Streptococcus cremoris UC503 and related lactic streptococci. PhD thesis, The National University of Ireland, University College Cork.

Couturier, M., Bex, F., Bergquist, P. L. \& MaAs, W. K. (1988). Identification and classification of bacterial plasmids. Microbiological Reviews 52, 375-395.

Ehrlich, S. D., Noirot, P., Petit, M. A., Janniere, L., Michel, B. \& TE RIELE, H. (1986). Structural instability of Bacillus subtilis plasmids. In Genetic Engineering, vol. 8, pp. 71-83. Edited by J. K. Setlow \& A. Hollaender. New York: Plenum.

Falkow, S., Guerry, P., Hedges, R. W. \& Datta, N. (1974) Polynucleotide sequence relationships among plasmids of the I incompatibility complex. Journal of General Microbiology 85, 65-76.

Gasson, M. J. (1983). Plasmid complements of Streptococcus lactis
NCDO 712 and other lactic streptococci after protoplast-induced curing. Journal of Bacteriology 154, 1-9.

Gruss, A. \& EhrLich, S. D. (1989). The family of highly interrelated single-stranded deoxyribonucleic acid plasmids. Microbiological Reviews 53, 231-241.

Harrington, A. \& Hill, C. (1991). Construction of a bacteriophageresistant derivative of Lactococcus lactis subsp. lactis $425 \mathrm{~A}$ by using the conjugal plasmid pNP40. Applied and Environmental Microbiology 57, 3405-3409.

Hayes, F., Daly, C. \& Fitzgerald, G. F. (1990). Identification of the minimal replicon of Lactococcus lactis subsp. lactis UC317 plasmid pCI305. Applied and Environmental Microbiology 56, 202-209.

Hayes, F., Vos, P., Fitzgerald, G. F., de Vos, W. M. \& Daly, C. (1991). Molecular organisation of the minimal replicon of the narrow host-range lactococcal plasmid pCI305. Plasmid 25, 16-26.

HoLO, H. \& NES, I. F. (1989). High frequency transformation by electroporation of Lactococcus lactis ssp. cremoris grown in glycine in osmotically stabilised media. Applied and Environmental Microbiology 55, 3119-3123.

Iordanescu, S., Surdeanu, M., Dell Latta, P. \& Novick, R. (1978). Incompatibility and molecular relationships between small staphylococcal plasmids carrying the same resistance marker. Plasmid 1, 468-479.

Law, J., Vos, P., Hayes, F., Daly, C., De Vos, W. M. \& Fitzgerald, G. F. (1992). Cloning and partial sequencing of the proteinase gene complex from Lactococcus lactis subsp. lactis UC317. Joumal of General Microbiology 138, 709-718.

Leenhouts, K. J., Tolner, B., Bron, S., KoK, J., Venema, G. \& SEEGERS, J. F. M. L. (1991). Nucleotide sequence and characterisation of the broad-host-range lactococcal plasmid pWV01. Plasmid 26, 55-66.

VAN DER Lelie, D., VAN DeR VosSen, J. M. B. M. \& Venema, G. (1988). Effect of plasmid incompatibility on DNA transfer to Streptococcus cremoris. Applied and Environmental Microbiology 54, 865-871.

LiN, L.-S., KIM, Y.-J. \& MEYER, R. J. (1987). The 20 bp directly repeated DNA sequence of the broad host-range plasmid R1162 exerts incompatibility in vivo and inhibits R1162 DNA replication in vitro. Molecular and General Genetics 208, 390-397.

MANEN, D. \& CARO, L. (1991). The replication of plasmid pSC101. Molecular Microbiology 5, 233-237.

Maniatis, T., Fritsch, E. F. \& SAmbrooK, J. (1982). Molecular Cloning: a Laboratory Manual. Cold Spring Harbor, NY: Cold Spring Harbor Laboratory.

MCKAY, L. L. \& BALdwin, K. A. (1984). Conjugative 40-megadalton plasmid in Streptococcus lactis subsp. diacetylactis DRC3 is associated with resistance to nisin and bacteriophage. Applied and Environmental Microbiology 47, 68-74.

Muriana, P. M. \& KlaEnhammer, T. R. (1987). Conjugal transfer of plasmid-encoded determinants for bacteriocin production and immunity in Lactobacillus acidophilus 88. Applied and Environmental Microbiology 53, 553-560.

MURPHY, M. C. (1988). Characterisation of the reduced bacteriophage sensitivity encoded by plasmid pCI750 from Streptococcus cremoris UC653. PhD thesis, The National University of Ireland, University College Cork.

Novick, R. P. (1987). Plasmid incompatibility. Microbiological Reviews 51, 381-395.

Novick, R. P. (1989). Staphylococcal plasmids and their replication. Annual Review of Microbiology 43, 537-565.

Novick, R. P., Clowes, R. C., Cohen, S. N., Curtiss, R., III, Datta, N. \& FALKow, S. (1976). Uniform nomenclature for bacterial plasmids: a proposal. Bacteriological Reviews 40, 168-189.

Persson, C. \& Nordstrom, K. (1986). Control of replication of the broad host range plasmid RSF1010: the incompatibility determinant consists of directly repeated DNA sequences. Molecular and General Genetics 203, 189-192.

Posno, M., Leer, R. J., van Luijk, N., van Giezen, M. J. F., Heuvelmans, P. T. H. M., Lokman, B. C. \& Polwels, P. H. (1991). Incompatibility of Lactobacillus vectors with replicons derived from small cryptic Lactobacillus plasmids and segregational instability of the introduced vectors. Applied and Environmental Microbiology 57, $1822-1828$. 
Simon, D. \& Chopin, A. (1988). Construction of a vector plasmid family and its use for molecular cloning in Streptococcus lactis. Biochimie 70, 559-566.

SoutherN, E. M. (1975). Detection of specific sequences among DNA fragments separated by gel electrophoresis. Journal of Molecular Biology 98, 503-517.

TERZAGHI, B. E. \& SANDINE, W. E. (1975). Improved medium for lactic streptococci and their bacteriophages. Applied Microbiology 29, 807-813.

UDO, E. E. \& GrUBB, W. B. (1991). A new incompatibility group plasmid in Staphylococcus aureus. FEMS Microbiology Letters $\mathbf{7 8}$, 33-36.

DE Vos, W. M. (1986). Genetic improvement of starter streptococci by the cloning and expression of the gene coding for a non-bitter proteinase. In Biomolecular Engineering in the European Community, pp. 465-471. Edited by E. Magnien. Dordrecht: Martinus Nijhoff.
DE Vos, W. M. (1987). Gene cloning and expression in lactic streptococci. FEMS Microbiology Reviews 46, 281-295.

de Vos, W. M., Vos, P., de HaArd, H. \& Boerrigter, I. (1989). Cloning and expression of the SK 11 gene encoding an extracellular serine proteinase. Gene 85, 169-176.

VAN der Vossen, J. M. B. M., KoK, J. \& Venema, G. (1985). Construction of cloning and promoter-screening shuttle vectors for Bacillus subtilis and Streptococcus lactis. Applied and Environmental Microbiology 50, 540-542.

WARREN, G. \& SHERRATT, D. (1978). Incompatibility and transforming efficiency of ColE1 and related plasmids. Molecular and General Genetics 161, 39-47.

WirTh, R., AN, F. Y. \& Clewell, D. B. (1986). Highly efficient protoplast transformation system for Streptococcus faecalis and a new Escherichia coli-S. faecalis shuttle vector. Journal of Bacteriology 165, 831-836. 